\title{
Pengaruh Kekuatan Media Sosial dalam Pengembangan Kesenjangan Digital
}

\author{
Dyah Listianing Tyas $^{1}$, A. Djoko Budiyanto ${ }^{2}$, Alb. Joko Santoso ${ }^{3}$ \\ ${ }^{1,2,3}$ Magister Teknik Informatika, Universitas Atma Jaya, Yogyakarta \\ Email: 'dyahlistianingtyas@gmail.com
}

\begin{abstract}
Abstrak
Langkah yang terbaik untuk mengurangi kesejangan digital adalah menyiapkan masyarakat untuk bisa menerima, menilai, memutuskan dan memilih informasi yang tersedia. Penyiapan kondisi psikologis bagi masyarakat untuk menerima, menilai, memutuskan dan memilih informasi bagi diri mereka sendiri akan lebih efektif dan mendewasakan masyarakat untuk bisa mengelola informasi dengan baik. Kemajuan teknologi informasi seseorang atau masyarakat akan mendapat kemudahan akses untuk menggunakan dan memperoleh informasi. Kemajuan teknologi informasi akan mendorong penggunaan internet yang positif. Seperti penggunaan media sosial yang masih menjadi tren disemua kalangan. Hasil dari penelitian ini akan menunjukkan beberapa pengaruh media sosial dalam pengembangan kesenjangan digital.
\end{abstract}

Kata Kunci: Media Sosial, Kesenjangan Digital

\section{PENDAHULUAN}

Sebagai salah satu negara berkembang (di Indonesia), perkembangan masyarakat informasi ditandai dengan munculnya industri media seperti media cetak (surat kabar, majalah, tabloid, dll) dan juga media elektronik (radio dan televisi). Masyarakat informasi adalah istilah yang digunakan untuk menggambarkan suatu kelompok masyarakat yang dapat melakukan dan membuat kemungkinan terbaik dalam menggunakan informasi dan teknologi komunikasi terbaru. Tingkat kebutuhan informasi yang tinggi dalam kehidupan masyarakat seperti ditandai pada penggunaan teknologi informasi untuk kegiatan sosial, pengajaran dan bisnis, serta kemampuan pertukaran data digital yang cepat dalam jarak yang jauh, menjadi ciri utama dari masyarakat informasi itu sendiri.

Dalam melakukan implementasi teknologi dibutuhkan keterampilan dalam mengoperasikan teknologi tersebut. Perkembangan teknologi seringkali menjadi sebuah inovasi, yaitu sesuatu hal yang baru, sehingga terkadang tidak mudah bagi suatu masyarakat untuk dapat menerima hal tersebut karena secara perspektif masih kerap terikat pada budaya-budaya yang lama, apalagi di Negara seperti Indonesia yang masih menjunjung tinggi budaya dan tradisi yang diadopsi secara turun menurun. Kemudian cara pemakaian dari teknologi itu sendiri yang seringkali bertolak belakang dengan nilai-nilai budaya yang konvensional menjadi penghambat munculnya inovasi dalam dunia teknologi dapat diterima secara lebih cepat dan terbuka

Kesenjangan digital merupakan salah satu dampak dari adanya hambatan-hambatan dalam pengimplementasian teknologi seperti pada contoh di atas. Kesenjangan digital juga dapat diartikan sebagai kesenjangan digital yang mengacu pada fakta bahwa ada sekelompok orang yang dikategorikan dalam masyarakat yang mampu dalam konteks ekonomi yang dapat menikmati akses dan menggunaan berbagai teknologi modern, 
sedangkan kelompok lain yang dikategorikan pada masyarakat ekonomi bawah tidak dapat melakukannya [1]. Kesenjangan digital bukan hanya berbicara mengenai kesenjangan mengenai akses terhadap Teknologi Informasi dan Komunikasi (TIK)nya saja tetapi juga pada kemampuan tiap individu dalam menggunakan TIK baik mengenai cara mengakses internet maupun penggunaannya.

Dampak positif kesenjangan digital bagi sebagian orang yang belum mengenal atau menerapkan teknologi adalah masyarakat dapat termotifasi untuk ikut ambil bagian dalam peningkatan teknologi informasi. Dampak negatif kesenjangan digital adalah bagi mereka yang mampu menghasilkan teknologi dan sekaligus memanfaatkan teknologi memiliki peluang lebih besar untuk mengelola sumber daya ekonomi, sementara yang tidak memiliki teknologi harus puas sebagai penonton saja. Akibatnya yang kaya semakin kaya dan yang miskin tetap miskin.

Sumber Daya Manusia sangat berpengaruh dalam dunia ilmu teknologi dan informasi, karena Sumber Daya Manusia ini menentukan biasa tidaknya seorang mengoperasikan atau mengakses sebuah informasi. Seiring dengan perkembangan teknologi informasi tersebut, tingkat pertumbuhan ekonomi masyarakat juga mengalami perkembangan dimana kebutuhan masyarakat kian meningkat terutama dalam bidang komunikasi.

Sumber Daya Manusia ini sangat penting dalam mengaplikasikan segala bentuk teknologi yang dimiliki oleh suatu lembaga. Terlebih lagi ditengah hiruk pikuknya era informasi yang mengakibatkan segalanya berubah dengan cepat, mau tak mau menuntut adanya Sumber Daya Manusia yang bermutu yang mampu menyesuaikan diri dengan segala bentuk perubahan yang sedang terjadi.

Perkembangan teknologi yang secanggih apapun, orientasi manusia tetap sangat penting karena dengan kehadiran dan pemanfaatan teknologi yang paling canggih pun unsur manusia tetap merupakan unsur yang paling penting [2].

Artikel ini membahas pemanfaatan internet terhadap kesenjangan digital pada masyarakat di Kota Pekalongan dan mengetahui Sumber Daya Manusia terhadap kesenjangan digital pada masyarakat di Kota Pekalongan.

\section{METODE}

\subsection{Pengertian Kesenjangan Digital}

Kesenjangan digital di era teknologi informasi saat ini menjadi perhatian penting di berbagai negara untuk mewujudkan pemerataan pembangunan di bidang teknologi informasi, salah satunya yaitu di Indonesia.

Pengertian kesenjangan digital menurut Instruksi Presiden No 3 Tahun 2003 tentang kebijakan dan strategi nasional pengembangan e-government didefinisikan dengan keterisolasian dari perkembangan global karena tidak mampu memanfaatkan informasi. Selain itu juga disebutkan bahwa ketidakmampuan menyesuaikan diri dengan kecenderungan global akan membawa bangsa Indonesia ke dalam jurang digital divide yaitu keterisolasian dari perkembangan global karena tidak mampu memanfaatkan informasi [3]. 
Menurut OECD (2001) Dalam Zulkarimen [4], kesenjangan digital (digital divide) merupakan jurang antara individu, rumah tangga, kawasan bisnis dan geografis pada berbagai tingkatan sosio-ekonomik dalam hal kesempatan mengakses Teknologi Informasi dan Komunikasi dan menggunakan internet untuk bermacam kegiatan.

Kesenjangan digital atau yang lebih dikenal sebagai digital divide yaitu keadaan dimana terjadi gap antara mereka yang dapat mengakses internet melalui infrastruktur teknologi informasi dengan mereka yang sama sekali tidak terjangkau oleh teknologi tersebut [4].

Dengan demikian digital divide didefinisikan kesenjangan (gap) antara individu, rumah tangga, bisnis, (atau kelompok masyarakat) dan area geografis pada tingkat sosial ekonomi yang berbeda dalam hal kesempatan akses TIK dan penggunaan internet untuk beragam aktivitas. Di Indonesia banyak dijumpai kesenjangan digital dilingkup pemerintahan tentang implementasi e-government sehingga dapat menghambat tujuan dalam penerapan $e$-government terutama di Indonesia.

\subsection{Aspek Kesenjangan Digital}

Kesenjangan digital merupakan ketidaksetaraan pengembangan, penyebaran, dan penggunaan teknologi media digital dalam berbagai lapisan masyarakat dan juga beragam aspek kehidupan seperti pada sosial, ekonomi, dan politik. Dalam kesenjangan digital, terdapat tiga aspek utama yang saling berhubungan dan merupakan fokus yang perlu diperhatikan [5] yaitu:

1) Akses/infrastruktur (access/infrastructure) adalah perbedaan kemampuan antar individu dalam perolehan akses atau infrastruktur TIK yang menyebabkan perbedaan distribusi informasi.

2) Kemampuan (skill and training) adalah perbedaan kemampuan antar individu dalam memanfaatkan atau menggunakan akses dan infrastruktur yang telah diperoleh. Selanjutnya adalah perbedaan antar individu dalam upaya pencapaian kemampuan TIK yang dibutuhkan untuk dapat memanfaatkan akses dan infrastruktur.

3) Isi informasi (content/resource) adalah Perbedaan antar individu dalam memanfaatkan informasi yang tersedia setelah seseorang dapat mengakses dan menggunakan teknologi tersebut sesuai dengan kebutuhannya.

Menurut Zulkarimen beberapa faktor yang diidentifikasi berpengaruh terhadap kesenjangan digital antara lain [4]:

1) Jalan ke akses telekomunikasi.

2) Akses ke internet.

3) Pencapaian pendidikan juga menjelaskan perbedaan akses.

4) Bahasa (hampir 90\% isi internet dalam bahasa Inggris).

5) Akses di kawasan kota lebih baik daripada desa.

Akses ke teknologi informasi merupakan kunci pembuka pintu untuk memasuki era ekonomi berbasis pengetahuan. Begitu pula dengan akses internet, masyarakat dapat memperoleh segala informasi yang mereka butuhkan yang dapat menjadi peluang untuk meningkatkan taraf kehidupan mereka [4].

\subsection{Media Sosial}

Pada dasarnya media sosial merupakan perkembangan mutakhir dari teknologiteknologi web baru berbasis internet, yang memudahkan semua orang untuk dapat 
berkomunikasi, berpartisipasi, saling berbagi dan membentuk sebuah jaringan secara online, sehingga dapat menyebarluaskan konten mereka sendiri. Post di blog, tweet, atau video YouTube dapat direproduksi dan dapat dilihat secara langsung oleh jutaan orang secara gratis [6].

Media sosial mempunyai banyak bentuk, diantaranya yang paling populer yaitu microblogging (Twitter), Facebook, dan blog. Twitter adalah suatu situs web yang merupakan layanan dari microblog, yaitu suatu bentuk blog yang membatasi ukuran setiap post-nya, yang memberikan fasilitas bagi pengguna untuk dapat menuliskan pesan dalam Twitter update hanya berisi 140 karakter. Twitter merupakan salah satu media sosial yang paling mudah digunakan, karena hanya memerlukan waktu yang singkat tetapi informasi yang disampaikan dapat langsung menyebar secara luas [6].

\subsection{Metodologi Penelitian}

\subsubsection{Lokasi}

Lokasi yang digunakan sebagai objek pada artikel ini adalah masyarakat Kota Pekalongan yang telah menggunakan layanan media sosial. Penelitian ini akan dilaksanakan pada 4 wilayah di Kota Pekalongan yaitu wilayah Pekalongan utara, Pekalongan selatan, Pekalongan timur, dan Pekalongan barat

\subsubsection{Populasi}

Menurut Sugiyono, populasi adalah wilayah generalisasi yang terdiri atas obyek/subyek yang mempunyai kualitas dan karakteristik tertentu yang ditetapkan oleh peneliti untuk dipelajari dan kemudian ditarik kesimpulannya [7]. Populasinya adalah masyarakat Kota Pekalongan yang berusia 17 - 58 tahun yang terbagi dalam 4 wilayah yaitu Pekalongan utara, Pekalongan timur, Pekalongan selatan dan Pekalongan barat yang berjumlah 201.323 jiwa.

\subsubsection{Sampel}

Menurut Sugiyono (2011), sampel adalah bagian dari jumlah dan karakteristik yang dimiliki oleh populasi tersebut. Sampel yang ambil harus betul-betul representatif (dapat mewakili) [7]. Sampel merupakan bagian dari populasi yang menjadi objek penelitian. Besar sampel diukur dengan rumus Slovin [8] :

$$
\mathrm{n}=\frac{\mathrm{N}}{1+\mathrm{N} \cdot\left(\mathrm{d}^{2}\right)}
$$

Dimana:

$\mathrm{n}=$ Ukuran Sampel

$\mathrm{N}=$ Ukuran Populasi

$\mathrm{d}=$ Persentase ketidaktelitian karena kesalahan pengambilan sampel yang masih dapat diinginkan.

Nilai presisi (d) yang dikehendaki peneliti pada taraf signifikasi $(\alpha=0,1)$ atau dengan tingkat kepercayaan $90 \%$. Besarnya sampel dalam penelitian ini menurut perhitungan rumus yang tertulis di atas yaitu:

$$
\begin{aligned}
& n=\frac{7629}{1+7629 \times(0,1)^{2}} \\
& \mathrm{n}=\frac{7629}{1+7629 \times(0,01)}
\end{aligned}
$$




$$
\begin{aligned}
& \mathrm{n}=\frac{7629}{1+76,29} \\
& \mathrm{n}=\frac{7629}{77,29} \\
& \mathrm{n}=98,706
\end{aligned}
$$

Dari perhitungan tersebut didapatkan jumlah kisaran sampel sebanyak 99,71 responden. Sampel yang diteliti bersifat individu perorangan yang tidak mungkin berupa pecahan, kemudian dibulatkan oleh peneliti menjadi 100 responden.

\subsubsection{Pengujian Hipotesis}

Sebelum melakukan pengujian terhadap hipotesis yang diajukan dalam penelitian ini, maka perlu menguji model penelitian terlebih dahulu. Pengolahan data penelitian ini menggunakan multiple regression yang diformulasikan pada rumus (2).

$$
\mathrm{Y}=\mathrm{a}+\mathrm{b}_{1} \mathrm{X}_{1}+\mathrm{b}_{2} \mathrm{X}_{2}+\mathrm{e}
$$

Keterangan:

$\mathrm{Y}=$ Kesenjangan Digital

$\mathrm{a}=$ Konstanta

b (1 dan 2) = Koefisien regresi masing-masing $X$

$\mathrm{X}_{1}=$ Pemanfaatan Internet

$\mathrm{X}_{2}=$ Sumber Daya Manusia

$\mathrm{e}=$ Error item

\section{1) Uji F (secara bersama-sama)}

Uji $\mathrm{F}$ adalah alat untuk menguji signifikansi koefisien regresi pengaruh variabel independent $(\mathrm{X})$ terhadap variabel dependent $(\mathrm{Y})$ yang diuji secara bersama-sama.

$$
\begin{aligned}
& \text { Ho diterima bila } \mathrm{F}_{\text {hitung }} \leq \mathrm{F}_{\text {tabel }}\{\alpha ;(\mathrm{n}-\mathrm{k}-1)\} \\
& \text { Ho ditolak bila } \mathrm{F}_{\text {hitung }}>\mathrm{F}_{\text {tabel }}\{\alpha ;(\mathrm{n}-\mathrm{k}-1)\}
\end{aligned}
$$

\section{2) Uji t}

Pengujian hipotesis pada penelitian ini dilakukan secara parsial atau dengan menggimakan uji t. Pengujian secara parsial dilakukan untuk mengetahui apakah masing-masing variabel independen (pemanfaatan internet dan sumber daya manusia mempunyai pengaruh terhadap variabel dependen (kesenjangan digital).

Pengujian hipotesis secara parsial (uji t) dilakukan dengan membandingkan nilai $t$ hitung dengan $\mathrm{t}$ tabel atau melihat $p$ value masing-masing variabel. Apabila nilai $\mathrm{t}$ hitung < t tabel atau $p$ value $>\alpha$, maka Ha ditolak dan Ho diterima, dengan kata lain variabel independen secara individual tidak berpengaruh signifikan terhadap variabel dependen. Sebaliknya, apabila t hitung $>\mathrm{t}$ tabel atau $p$ value $<\alpha$ maka $\mathrm{H}$ a diterima dan Ho ditolak, dengan kata lain variabel independen secara individual berpengaruh signifikan terhadap variabel dependen. 


\section{3) Koefisien Determinasi $\left(\mathrm{R}^{2}\right)$}

Koefisien determinasi $\left(\mathrm{R}^{2}\right)$ adalah sebuah koefisien yang menunjukkan persentase pengaruh semua variabel independen terhadap variabel dependen. Persentase tersebut menunjukkan seberapa besar variabel independen dapat menjelaskan variabel dependennya. Semakin besar koefisien determinasinya semakin baik variabel-variabel independen dalam menjelaskan variabel dependen. Dengan demikian persamaan regresi yang dihasilkan baik untuk mengestimasi nilai variabel dependen.

\section{HASIL DAN PEMBAHASAN}

\subsection{Uji F}

Uji $\mathrm{F}$ digunakan untuk menguji apakah sekelompok variabel independen yaitu variabel Pemanfaatan Internet $\left(\mathrm{X}_{1}\right)$ dan variabel Sumber Daya Manusia $\left(\mathrm{X}_{2}\right)$ secara bersama-sama mempunyai pengaruh terhadap variabel dependen yaitu kesenjangan digital pada masyarakat di Kota Pekalongan (Y).

$$
\begin{aligned}
\mathrm{F}_{\text {tabel }} & =\alpha ; \mathrm{k}-1 ; \mathrm{n}-\mathrm{k} \\
& \\
& =0,05 ; 2-1 ; 100-2 \\
& =0,05 ; 1 ; 98 \\
& =3,94
\end{aligned}
$$

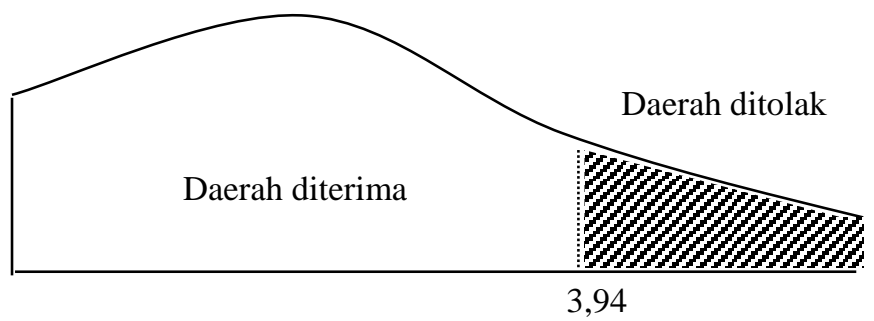

Gambar 1. Daerah ditolak dan diterima pada uji F

Berdasarkan hasil perhitungan seperti ditunjukkan pada Gambar 1 diperoleh Fhitung 19,305 > Ftabel 3,94 sehingga Ho ditolak, artinya variabel pemanfaatan internet $\left(\mathrm{X}_{1}\right)$ dan variabel Sumber Daya Manusia $\left(\mathrm{X}_{2}\right)$ secara bersama-sama mempunyai pengaruh signifikan terhadap kesenjangan digital pada masyarakat di Kota Pekalongan (Y).

\subsection{Uji t}

Uji t (Gambar 2 dan Gambar 3) digunakan untuk menguji apakah sekelompok variabel independen yaitu variabel Pemanfaatan Internet $\left(\mathrm{X}_{1}\right)$ dan variabel Sumber Daya Manusia $\left(\mathrm{X}_{2}\right)$ secara individu mempunyai pengaruh terhadap variabel dependen yaitu kesenjangan digital pada masyarakat di Kota Pekalongan (Y).

$$
\begin{aligned}
\mathrm{t}_{\text {tabel }} & =\alpha / 2 ; \mathrm{n}-\mathrm{k}-1 \\
& =0,05 / 2 ; 100-2-1 \\
& =0,025 ; 97 \\
& =1.98
\end{aligned}
$$




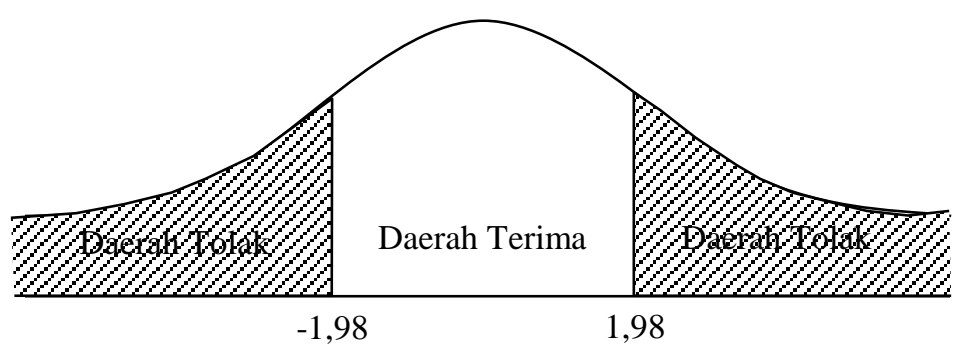

Gambar 2. Daerah ditolak dan diterima pada Uji t

1) Variabel Pemanfaatan Internet $\left(\mathrm{X}_{1}\right)$ terhadap variabel kesenjangan digital pada masyarakat di Kota Pekalongan (Y)

Perhitungan $t_{\text {hitung }}$ untuk variabel Pemanfaatan Internet $\left(\mathrm{X}_{1}\right)$ diperoleh nilai $\mathrm{t}_{\text {hitung }}=$ $2,514>$ nilai $t_{\text {tabel }}=1,98$ sehingga $\mathrm{H}_{0}$ ditolak, artinya variabel Pemanfaatan Internet $\left(\mathrm{X}_{1}\right)$ berpengaruh signifikan terhadap variabel kesenjangan digital pada masyarakat di Kota Pekalongan (Y).

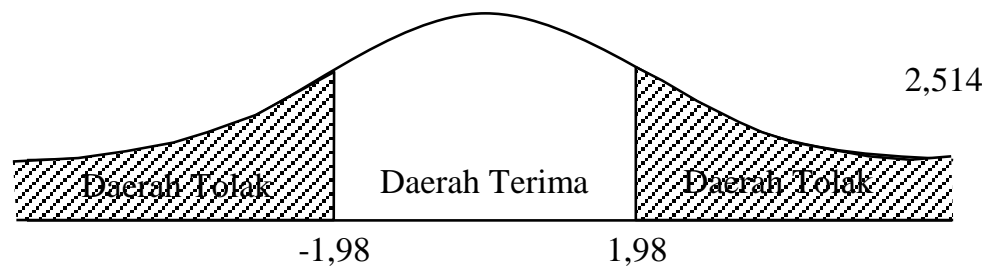

Gambar 3. Daerah ditolak dan diterima pada variabel pemanfaatan internet $\left(\mathrm{X}_{1}\right)$ berpengaruh signifikan terhadap variabel kesenjangan digital pada masyarakat di Kota Pekalongan (Y)

2) Variabel Sumber Daya Manusia $\left(X_{2}\right)$ terhadap variabel kesenjangan digital pada masyarakat di Kota Pekalongan (Y)

Perhitungan $t_{\text {hitung }}$ untuk variabel Sumber Daya Manusia $\left(\mathrm{X}_{2}\right)$ diperoleh nilai $\mathrm{t}_{\text {hitung }}=$ $2,634>$ nilai $\mathrm{t}_{\text {tabel }}=1,98$ sehingga $\mathrm{H}_{0}$ ditolak, artinya variabel Sumber Daya Manusia $\left(\mathrm{X}_{2}\right)$ berpengaruh signifikan terhadap variabel kesenjangan digital pada masyarakat di Kota Pekalongan (Y) seperti ditunjukkan pada Gambar 4.

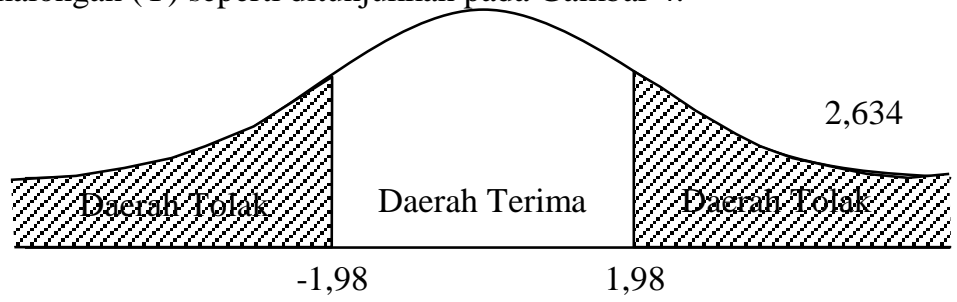

Gambar 4. Daerah ditolak dan diterima pada variabel Sumber Daya Manusia $\left(\mathrm{X}_{2}\right)$ terhadap variabel kesenjangan digital pada masyarakat di Kota Pekalongan (Y) 


\subsection{Pengujian Koefisien Determinasi (Adjusted $\mathbf{R}^{2}$ )}

Berdasarkan hasil uji determinasi diketahui bahwa nilai adjusted $\mathrm{R}$ square sebesar 0,659 , yang mengandung arti bahwa $65,9 \%$ variasi besarnya variabel kesenjangan digital pada masyarakat di Kota Pekalongan (Y) bisa dijelaskan oleh variasi variabel Pemanfaatan internet $\left(\mathrm{X}_{1}\right)$ dan variabel Sumber Daya Manusia $\left(\mathrm{X}_{2}\right)$. Sedangkan sisanya $34,1 \%$ lainnya dijelaskan oleh variabel lain di luar model

\section{SIMPULAN}

Variabel pemanfaatan internet dan variabel Sumber Daya Manusia secara bersamasama mempunyai pengaruh signifikan terhadap kesenjangan digital pada masyarakat di Kota Pekalongan.Variabel pemanfaatan internet berpengaruh signifikan terhadap variabel kesenjangan digital pada masyarakat di Kota Pekalongan. Variabel Sumber Daya Manusia berpengaruh signifikan terhadap variabel kesenjangan digital pada masyarakat di Kota Pekalongan.

\section{REFERENSI}

[1] Baase, S. 2012. A Gift of Fire Social, Legal, and Ethical Issues for Computing Technology 4th. Prentice Hall PTR, New Jersey.

[2] Siagian, S. P. 2009. Kiat Meningkatkan Produktivitas Kerja. Rineka Cipta, Jakarta

[3] Inpres. 2003. Kebijakan dan Strategi Nasional, Jakarta.

[4] Zulkarimen, N. 2007. Komunikasi Pembangunan, Pengenalan Teori dan Penerapannya. Raja Grafindo Persada. Jakarta.

[5] Camacho, K. 2005. Digital Divide, Multicultural Perspectives on Information Societies, $C \&$ \& Editions ed.

[6] Zarrella, D. 2010. The Social Media Marketing Book. Serambi Ilmu Semesta, Jakarta.

[7] Sugiyono. 2011. Metode Penelitian Bisnis. Alfabeta, Bandung.

[8] Riduwan. 2005. Skala Pengukuran Variabel-Variabel Penelitian. Alfabeta, Bandung.

[9] SIBIS. 2003. Statistical Indicators Benchmarking the Information Society, [Online]. Available: http://www.sibis-eu.org . [Diakses 21 Maret 2015]. 